\title{
Can the kisspeptin help us in the understanding of pathology of some neurodegenerative brain diseases?
}

\author{
N. Melka', A. Pszczolinska1', I. Klejbor'2, 3, B. Ludkiewicz'1, P. Kowiański1, 3, J. Moryśs, 4 \\ ${ }^{1}$ Department of Anatomy and Neurobiology, Faculty of Medicine, Medical University of Gdansk, Poland \\ ${ }^{2}$ Department of Anatomy, Jan Kochanowski University of Kielce, Poland \\ ${ }^{3}$ Department of Clinical Anatomy and Physiology, Institute of Health Sciences, Pomeranian University of Slupsk, Poland \\ ${ }^{4}$ Department of Normal Anatomy, Faculty of Medicine and Dentistry, Pomeranian Medical University in Szczecin, Poland
}

[Received: 20 August 2021; Accepted: 10 September 2021; Early publication date: 15 September 2021]

\begin{abstract}
It is already known that the discovery of kisspeptin was a revolutionary step in the understanding of neuroendocrine regulation of reproduction. Kisspeptin is one of the main moderators of the gonadotropic axis, but the kisspeptin gene is known to be expressed in various regions of the central nervous system. The activity of kisspeptin is not limited to hypothalamic pituitary gonadal axis; it participates in the regulation of multiple neuronal circuits in the limbic system. The limbic system is a part of the brain involved in behavioural and emotional reactions, and disturbances in its functioning may be the source of some psychiatric as well as degenerative disorders. In the present review, we summarise the current state of knowledge concerning the role of kisspeptin in the limbic system and a new hope for the treatment of disturbances in its functioning. (Folia Morphol 2021; 80, 4: 756-765)
\end{abstract}

Key words: kisspeptin, hypothalamus, limbic system, neurodegenerative disease

\section{INTRODUCTION}

Kisspeptin (KP), a protein named after the famous chocolates 'Kisses', has revolutionised both our knowledge of hypothalamic pituitary gonadal (HPG) axis $[29,56,90]$ and the understanding of neuroendocrine regulation of reproduction $[29,56,90]$. Kisspeptin bases on the principle of feedback which allows for the maintaining of homeostasis in various physiological states of the body. The first information about the KP protein and its influence on the function of HPG axis appeared at the end of the $20^{\text {th }}$ century during the studies on the function of dynorphin $A$ and neurokinin $B[15,48]$. The HPG works mainly due to the interaction and integration of brain and gonadal signals $[44,104]$. In the rat, the oestrogen receptor is not present on gonadotropin-releasing hormone (GnRH) neurons [47]; consequently, gonadal feedback must be realised by the intermediate signalling pathway. The protagonist of this route is KP $[38,50,51,56,89]$. Kisspeptin plays a decisive role in the control of fertility by initiating and regulating the process of puberty and pituitary secretion. Since 2005, it has been known to be the strongest activator of the HPG axis [43]. Depriving KP or its receptor weakens fertility and reproductive physiology $[28,30$, 89], while enhancement of the mutation function in

Address for correspondence: Prof. J. Moryś, Department of Normal Anatomy, Faculty of Medicine and Dentistry, Pomeranian Medical University in Szczecin, ul. Powstańców Wielkopolskich 72, 70-111 Szczecin, Poland, e-mail: neurob2010@me.com

This article is available in open access under Creative Common Attribution-Non-Commercial-No Derivatives 4.0 International (CC BY-NC-ND 4.0) license, allowing to download articles and share them with others as long as they credit the authors and the publisher, but without permission to change them in any way or use them commercially. 


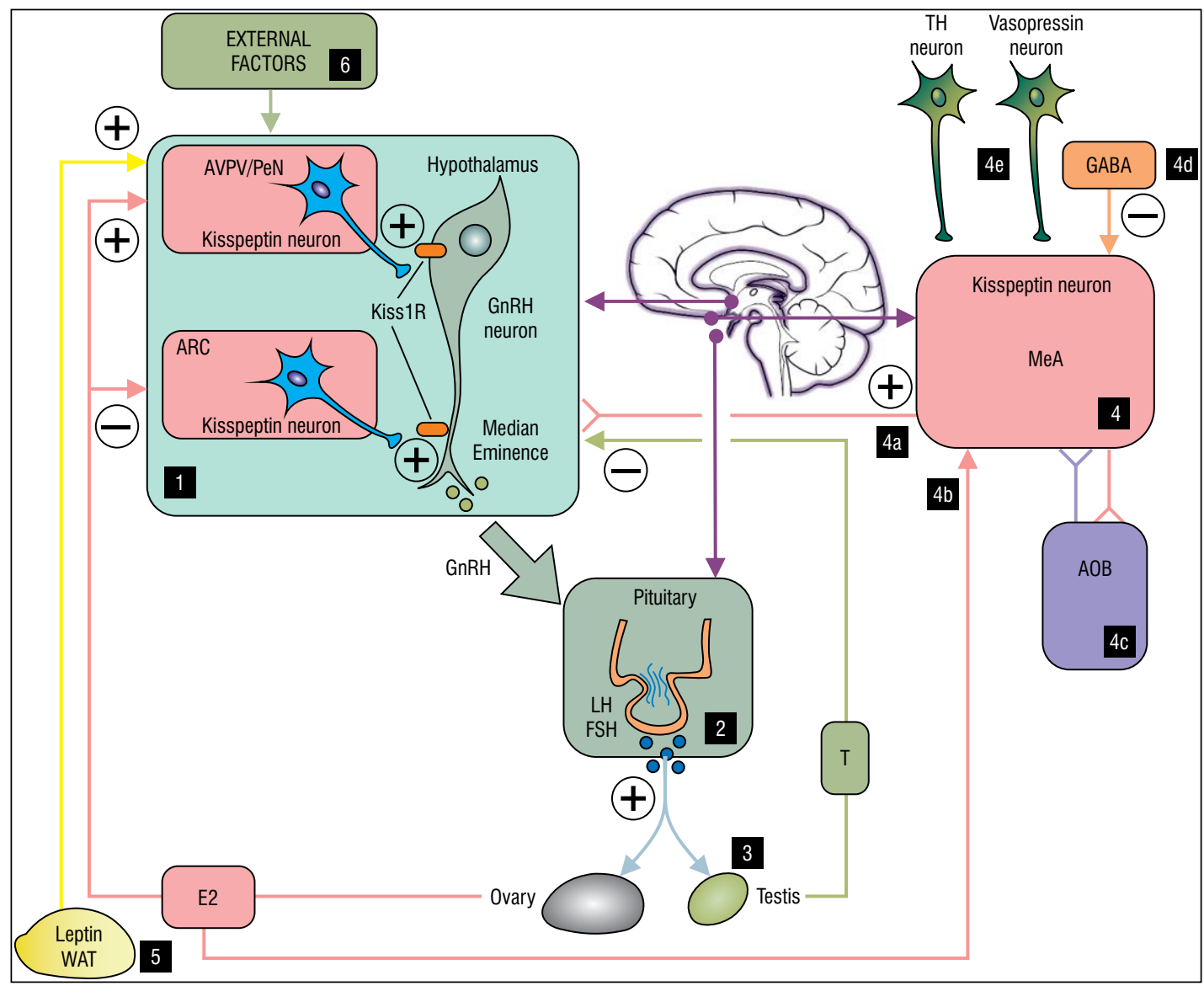

Figure 1. Diagram summarizing the integrated function of the major populations of kisspeptin neurons. 1. The primary functions of hypothalamic kisspeptin are its roles in stimulating reproduction and mediating sex steroid feedback signalling. Kisspeptin neurons are situated in the anterior ventral periventricular region (AVPV), periventricular nucleus (PeN) and arcuate nucleus (ARC) of the hypothalamus. The diagram shows the effect of kisspeptin neurons on GnRH neurons depending on the place of occurrence. In the case of AVPV/PeN, it is a body cell, while for ARC, it is a median eminence. Sex steroid hormones inhibit the expression of Kiss1 in the ARC and induce expression in the AVPV/ PeN. When sex steroids are low, Kiss1 expression increases in ARC and decreases in AVPV/PeN. Major elements having reproductive control are hypothalamic GnRH neurons that release GnRH into the bloodstream system. GnRH influences FSH and LH gonadotropins, which in turn regulate gonadal function [29, 56, 90, 103]; 2. Pituitary: synthesize and secrete gonadotropin hormones [luteinizing hormone (LH) and follicle-stimulating hormone (FSH)]; 3. Gonads: gamete generation and the production of sex hormones such as oestrogen and testosterone; 4. The third big population of kisspeptin neurons (in addition to those present in the hypothalamus) is present in the medial nucleus of amygdala (medial amygdala, MeA) [42]; 4a. Kisspeptin neurons from MeA send axons to the preoptic area of hypothalamus (POA) where many $\mathrm{GnRH}$ neurons are present [78]; 4b. Oestradiol (E2) acts on MeA kisspeptin neurons via oestrogen receptor $\alpha(E r \alpha)$ [95, 96]; 4c. Kisspeptin neurons in MeA are reciprocally linked to the accessory olfactory bulb (AOB) [57, 78]; 4d. Kisspeptin neurons in MeA are downregulated by GABA signalling via gamma-aminobutyric acid $B$ (GABAB) receptor [34]; 4e. Kisspeptin neurons in MeA get projections from vasopressin and tyrosine hydroxylase (TH) neurons [78]; 5. Leptin, produced by white adipose tissue (WAT), has a stimulating effect on the activity of GnRH hypothalamic neurons. Kisspeptin neurons are present in the group of intermediate neurons that have leptin receptors [86]; 6. Effect of external factors on kisspeptin neurons in hypothalamus, like stress, age, nutrition, and pheromones [85, 88].

the KISS1R results in premature maturation [100]. In immature rats, administration of KP induced the onset of maturation, while administration of its antagonist delayed it [77].

Kisspeptin is encoded by the kisspeptin gene (KISS1/Kiss1 gene) [63]. This neuropeptide performs different roles in brain functions. It is dynamically regulated by neuronal activity and increases synaptic transmission for a long time [6]. The kisspeptin gene is expressed in the central nervous system $[21,36,56,64,65]$ as well as in many other organs [10]. Kisspeptins are the products of KISS1 gene, which operate trough the G-protein coupled receptor GPR54 [37] and are essential for stimulation of GnRH secretion and induction of puberty (Fig. 1). This receptor is highly expressed in the brain areas related to memory and emotions, including the hippocampus and amygdala [7]. The wide distribution of KP fibres, as well as the $\mathrm{KP}$ receptor in central and peripheral nervous system, is a reason for these proteins being involved in 
the regulation of multiple neuronal circuits and has been reported in a large number of physiological, as well as pathophysiological conditions of the reproductive system $[18,90,105]$, diabetes $[52,53,90]$, adiposity $[45,50]$ and suppression of metastasis in various neoplasm [17, 61], locomotor activity [98], and anxiety [98].

In all examined mammalian species, the localisation of hypothalamic KP neurons is mostly similar. They are generally placed in the anteroventral periventricular nucleus (AVPV) and the preoptic periventricular nucleus (PeN), dorsomedial nucleus (DMN), and arcuate nucleus (ARN) [1, 20,32, 41, 66]. A studied species contains at least two types of KP neurons in the hypothalamus [66], and another one in the medial amygdala of rodents [96]. The KP neurons are observed mainly in the preoptic/rostral hypothalamus in various mammalian species, including rodents $[20,42,92,93]$, sheep [36, 41], pigs [101], nonhuman primates [91, 102, 106] as well as human [84]. Due to different role of KP neurons, they additionally contain various neurotransmitters/neuromodulators or their precursors like galanin [55, 79], enkephalin [79], dopamine [19] or GABA and glutamine [26]. Additionally, in the human, KP neurons, the co-expression of neuropeptides including neurokinin $B$ [48], substance $P$ [49] and cocaineand amphetamine-regulated transcript CART were observed. The different co-transmitters present in the KP neurons suggest its multimodal functions and involvement in various behavioural activities in the brain structures.

Leptin, discovered in 1994, is known to be produced by white fatty tissue (WAT) [110] and to have a major indirect effect on excitation of HPG axis. This stimulatory effect on the HPG axis is performed through the KP interneurons located in the anterior part of the hypothalamus which also possess the receptors for leptin $[12,13,50]$. Additionally, many regulatory factors influence the hypothalamic KP neurons and consequently, the release of KP. Energy reserves are essential for reproductive success. As a result, metabolic factors tightly control the synthesis and release of KP [71].

\section{LIMBIC SYSTEM}

In 2011 scientists began to examine KP and its effects outside the hypothalamus more closely. The expression of KP was also found in other components of the limbic brain structures, like amygdala $[2,24$,
$57,60,78,95]$, hippocampus $[6-8,62]$ and olfactory system [78]. There are very few records regarding the expression of KISS1 mRNA in the striatum $[62,67]$.

The limbic system is a set of structures in the brain that are involved in memory and emotions as well as in reproductive behaviours [81]. However, the precise link connecting those functions is still elusive and undefined. Defects in the functioning of the limbic system can be a source of many diseases. In the past years, KP emerged as physiological regulator of GnRH neurons and, hence, of the HPG axis. Some reviews summarized this function of KP; however, they focused mainly on the presence and role of KP in the hypothalamus $[38,50,51,56,83]$. There are some reports presenting other functions of KP such as decreasing food intake, as well as being one of the new hypothalamic anorexigenic factors [94].

Emotion and sexual responses are fundamental in human behaviour. Researchers have shown KP as a link between the brain and the reproductive axis [24]. Kisspeptin administration enhances limbic and paralimbic system activity [24]. What is more, KP reduces sexual aversion and noticeably increases brain activity [24]. The author emphasizes KP participation in limbic system activity, behaviour, and modulation of sex hormones [24]. On top of it, KP administration decrease negative mood [24]. The results indicate that KP also shows antidepressant-like effects [24]. Kisspeptin administration activates components of the reward system such as the hippocampus, amygdala and the cingulate and enhances the activity of this system [24]. Additional research shows; that $\mathrm{KP}$ increases emotional and sexual processing and decreases sexual aversion. This gives green light to the kisspeptin-based therapies for emotional and psychosexual disorders [23].

The reaction of other species is also interesting. Kisspeptin, via activation of the HPG axis, as well as modulation of releasing testosterone, has indirect effects on aggressive and territorial behaviour in male lizards [72].

\section{BEHAVIOURAL AND NEURAL REACTIONS TO EMOTIONS}

The amygdala, emotional centre of the brain, is a part of the limbic system. It is closely related to anxiety, fear, reward, stress, and social behaviour [81]. The medial nucleus of amygdala (MeA) is a most important brain region in sexual and emotional reaction [81] in which Kiss1 neurons were first described in 


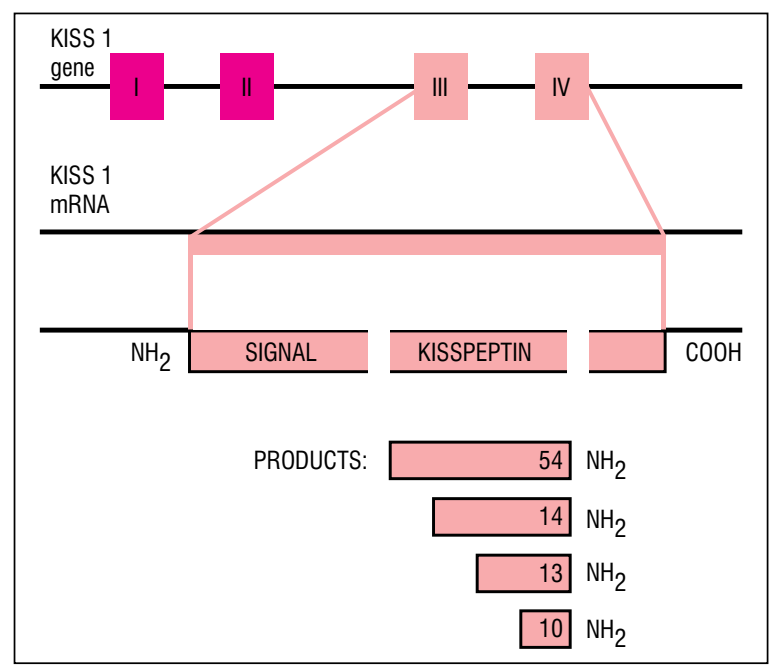

Figure 2. Kisspeptins are a family of small but important peptides that play a key role in the regulation of neuroendocrine reproductive function through the nervous pathways. The diagram demonstrates products of the KISS1 gene. Presented are the precursor kisspeptin-145 and the functional kisspeptin fragments: kisspeptin-54 and shorter peptides such as kisspeptin-14, kisspeptin-13, kisspeptin-10 (suffix showing the number of amino acids).

male mice in 2004 [42]. Neurons of MeA contain a lot of steroid hormone receptors which interact with the sex hormones and transfers olfactory information to areas closely related to KP like hypothalamic nuclei engaged in reproduction and defence (Fig. 2) [57]. Many studies on the amygdala indicate involvement of this structure in the regulation of female reproductive cycles and sexual behaviour [60]. It is known that the KP neurons present in MeA are the third largest population of these neurons in the brain [42, 96]. Today we know that MeA kisspeptin neurons are regulated by sex steroids (E2 via receptor) [95, 96] and GABA (via receptor) [34]. MeA kisspeptin neurons send efferent projections to the hypothalamus $[78,109]$ and are also interconnected with the accessory olfactory bulb (AOB) $[57,78]$. Additionally, they receive projections from vasopressin and $\mathrm{TH}$ neurons [78]. All this suggests that KP plays a much larger role in the regulation and functioning of the nervous system.

Kim et al. [60] were first to test the effect of sex steroids on rodent's MeA Kiss1 neurons. In the MeA, as in the AVPV/PeN, Kiss1 levels are highly regulated and dependent on the level of sex steroids [60]. According to Stephens et al. [95], Kiss1 expression in MeA neurons rises at puberty, and it is compatible with developmental level of sex steroids. The author's showed that Kiss 1 expression in the amygdaloid body is present only in pubertal period and is not expressed in MeA in the neonate or in the prepubertal period [95]. There is a relationship and dependence between amygdala KP signalling and the HPG axis. This is evidenced by observations on the direct KP administration into the medial amygdala which stimulate a luteinizing hormone (LH) secretion [22]. In turn, KP antagonist decreases in $\mathrm{LH}$ secretion.

Activation of KP neurons localized in the posterodorsal part of the medial amygdala (MePD) affects both social interaction and sexual partner preference in male mice [2]. Research on the activation of medial amygdala KP neurons shows increases of time spent by male mice investigating females [2]. It indicates a key role played by MePD kisspeptin in sexual and motivation behaviour.

\section{THE MISSING LINK: WHEN THE SMELL MEETS EMOTION}

Olfactory bulbs are an important part of the sexual behavioural system due to the presence of direct olfactory pathways to the corticomedial nuclei of the amygdala [58]. Within the olfactory system, two distinct sensory systems can be distinguished; the main olfactory system and accessory olfactory system [78]. The accessory olfactory bulb projects to MeA kisspeptin neurons [78] which are usually called "vomeronasal" amygdala [58]. This indicates the role of KP neurons in the processing of and responding to fragrance and pheromone information. Pheromones are detected and processed by accessory olfactory system which has been functionally linked to reproductive behaviour [11]. Next, signals triggered by pheromones in the accessory olfactory system are transmitted to hypothalamus [46]. The connection between the olfactory signals and the reproductive neuroendocrine axis is indicated by the latest results obtained by Aggarwal's team [3]. Hellier et al. [46] indicates that a reproductive success is an effect of close relationship of pheromone stimulation. Interestingly, the exact anatomical location of the KP receptor has not been described in the olfactory system so far.

Results obtained by Yang et al. [108] confirm the effect of KP on the structures of the limbic system. It is known that KP receptors are present in brain structures involved in emotions. The administration of KP significantly affects the reception of aromatic stimuli. The activity of the main olfactory network as well as structures such as the hippocampus and amygdala increase due to the nice smell [108]. In various neu- 
rodegenerative diseases, the impairment of olfactory functions is observed [4, 33]. In the Alzheimer's or Parkinson's disease, the loss of olfaction may precede memory or motor disturbances [35]. To administer proper neuroprotective therapies, an early recognition of degenerative symptoms of the nervous system is necessary [87]. According to the role of KP in the olfactory and limbic structure, we might suspect that kisspeptins are a novel therapeutic potential in neurodegenerative diseases as well as reproductive disturbances.

\section{FUNCTION OF KISSPEPTIN IN HIPPOCAMPUS}

The functional role of KP in the hippocampus is still unknown. Many studies prove that KP works in the hippocampus as a neuropeptide neuromodulator $[6,42,54,99]$. GPR54 is strongly expressed in the granular cell of hippocampal dentate gyrus [6-8], which is the first step of the hippocampal trisynaptic circuit. Lee et al. [62] showed that GPR54 density in the hippocampus is very high in the granule cell of the dentate gyrus, whereas it is barely detectable in the pyramidal cells of CA1 and CA3. Kisspeptin in the hippocampus rises the synaptic transmission via the activation of mitogen-activated protein kinases (MAPK)-related signalling pathway in granular cell of the dentate gyrus [8]. According to some authors, this regulatory system can play a role in the pathogenesis of epilepsy [6, 7]. Arai et al. [6-8] indicate that the neuronal activity strongly affects the expression of KP. They observed the greatest changes in KP expression after kainate injection [7], which is often used to obtain the model of temporal lobe epilepsy. Arai et al. [7] suggest the existence of positive feedback loop in the hippocampal formation. The excitability of granular cells is increased by the release of KP, which in turn has the effect of increasing the expression of KP [7]. The peptide system can play a role in epilepsy.

The dentate gyrus of the hippocampus is one of main neurogenic niches in the adult brain. Neural stem cells are located in this place and produce progenitors that travel near their final location like granular cell layer of the dentate gyrus [14]. The continuous addition of new granule cell population in the dentate gyrus has the potential to make a preferential participation to neural circuit transformation. There is possibility that KP and GPR54 are recruited to regulate neurogenesis in combination with other neurotrophic factors $[63,64]$. This is supported by the antimetastatic actions of KP $[63,64]$. The observations carried out by Arai et al. [8] show that activation of GPR54 by metastin reversibly increases excitatory synaptic transmission in the granule cells of dentate gyrus.

\section{NEW THERAPEUTIC APPROACH TO THE TREATMENT OF RECOGNITION MEMORY DISORDERS}

The Alzheimer's disease (AD) is associated with a loss of cognitive function due to the progressive loss of neurons and their synapses. Given the increasing incidence of $A D$, finding new effective therapeutic strategies is now of the utmost importance. The GPR54 mRNA is highly expressed in the hippocampus [6], what may indicate that KP might be engaged in learning and memory processes. Hippocampus has a critical role in control of learning and memory, and its damage causes dysfunction in the processing of memory, memory consolidation and recognition [80]. As the role of KP and GPR54 in recognition processes was unclear, Jiang et al. [54] were the first to undertake research into the relationship of the KP/GPR54 system in memory recognition. His research was inspired by a Telegdy and Adamik report [99] in which he pointed that KP makes learning and memory consolidation in mice easier.

In 2012 Milton et al. [68] underlines that AD involves changes in the functioning of the HPG axis. He shows that KP might be a factor preventing neurotoxicity of amyloid- $\beta$ peptide in vitro. Milton was the first to show in vitro interaction of KP with amyloid- $\beta$ peptide that suggests a potential role of $K P$ in $A D$ pathology [16]. Milton et al. [68] is a mastermind of the idea of using KP peptides in preventing, detecting and treating of diseases including Alzheimer's, Creutzfeldt-Jakob disease and type 2 diabetes. Three years later, Jiang et al. [54] shows that the injection of KP-13 into the lateral ventricle and hippocampus activates receptors GPR54, prolongs the memory retention, makes easier the creation of object recognition memory, and improves memory deficit.

The pyramidal neurons of the CA1 sector of the hippocampus are particularly damaged during $A D$ [97]. After the injection of amyloid- $\beta$ into the hippocampus, KP-13 shows neuroprotective effects, alleviates disorders, has positive effects on improving spatial memory, and significantly prevents neuronal loss [59]. Further research is needed to determine whether the neuroprotective effects of KP against 
amyloid- $\beta$ peptide toxicity are via direct binding to amyloid- $\beta$ peptide or via the receptor.

The wide expression of KP in structures involved in memory mechanisms and learning processes suggests interactions with cholinergic systems. Babaei et al. [9] indicate therapeutic function of KP. The injection of KP-13 into lateral cerebral ventricle had a positive effect on memory and facilitated spatial learning in induced AD. This endogenous peptide has an important role in alleviating the cognitive deficit by increasing the cholinergic response. As KP interacts with many neuropeptides involved in learning and memory, its action may be mediated through these receptor systems, which should be further investigated. Gamma-aminobutyric acid (GABA) is an example here. This is a key neurotransmitter and is closely related to behavioural disorders. Studies have shown that administration of KP highly reduces the level of GABA in the limbic system in humans [25]. Kissorphin, a peptide derived from KP-10, prevents acute impairment of memory, cognitive functions, and short-term spatial learning due to ethanol administration [39].

However, Kiss 1 expression is inhibited during metabolic stress $[82,86]$. It is suggested that an attenuation of KP signalling reduces metabolism as KP levels are inversely proportional to insulin secretion [5]. A decrease in KP signalling causes a decrease in brain metabolism [5].

\section{BEHAVIOURAL THEORY OF DEPRESSION AND KISSPEPTIN}

The limbic system seems to be involved in severe mental illnesses such as schizophrenia and depression. Base for depression is still incompletely understood and little is known about its pathogenesis [75]. One of the reasons is the lack of consensus on the pathology and aetiology of depression. Some symptoms' characteristics for depression are impossible to be modelled on laboratory animals. As of today, the criteria for identifying animal models of depression are based on actions of antidepressant drugs and responses to stress [107]. Animal models played big roles in the development of antidepressant drugs. Two of the most frequently used examinations are the open field test and the forced swim test. The open field is a very popular animal model of anxiety-like behaviour. The forced swim test is a behavioural test for rodents and is one of the most frequently used tests for evaluation of antidepressant drugs [76]. Tana- ka et al. [98] and Telegdy and Adamik [99] showed that KP-13 strongly influenced activity, climbing and swimming times. In this study, KP-13 displayed antidepressant-like effects in a forced swimming test [98]. In open field test, the injection of KP-13 into lateral cerebral ventricles stimulates the HPA axis which is the most important adaptive neuroendocrine system [40]. Kisspeptin-13 in the open field test has a big impact on behaviour in rats. In addition, KP-13 induces hyperthermia [27]. This suggests a potential role for $\mathrm{KP}$ in thermogenesis.

The observations carried out by Adekunbi et al. [2] focused on KP neuronal population in MeA which is involved in anxiety response. Adekunbi et al. [2], in contrast to Telegdy and Adamik's results [99], showed that the selective activation of MeA kisspeptin neurons reduced anxiety in mice. Injection of $\mathrm{KP}-13$ in rats reduced time spent in the open arms of the elevated-plus maze. Adekunbi's mice were less anxious which was evidenced by longer exploratory time in the open arms of the elevated plus maze [2]. Similar results were obtained in another experiment regarding the effect of KP on anxiety behaviour in male mice. Delmas et al. [31] focused on the role of KISS1R signalling in anxiety behaviour. Research shows a tendency for decreased anxiety behaviour in rapport to the elevated plus maze. Such differences in specificity likely result from differences between the two species. Further work is necessary to answer the questions about the role of KP signalling in anxiety in various species, as KP has an antidepressant role not only in rodents. Ogawa et al. [73] indicates that interaction between KP and the serotonergic system plays an important role in the modulation of fear in zebrafish. Later studies by his team showed that the blockade of serotonin receptors abolished the effect of $\mathrm{KP}$, which modulated the serotonergic system through glutamatergic neurotransmission [69, $70,74]$. The role of kisspeptin-based therapy requires further study and explanation as there are clear links between KP and anxiety.

\section{CONCLUSIONS}

Today, KP is undoubtedly one of the basic proteins regulating not only the mechanisms underlying reproductive functions, but also the neuronal networks that integrate sexual and emotional behaviour with reproductive functions (Fig. 3). To date, most of the data concentrate on the sexual role of KP in the central nervous system, so it will be of great interest in 


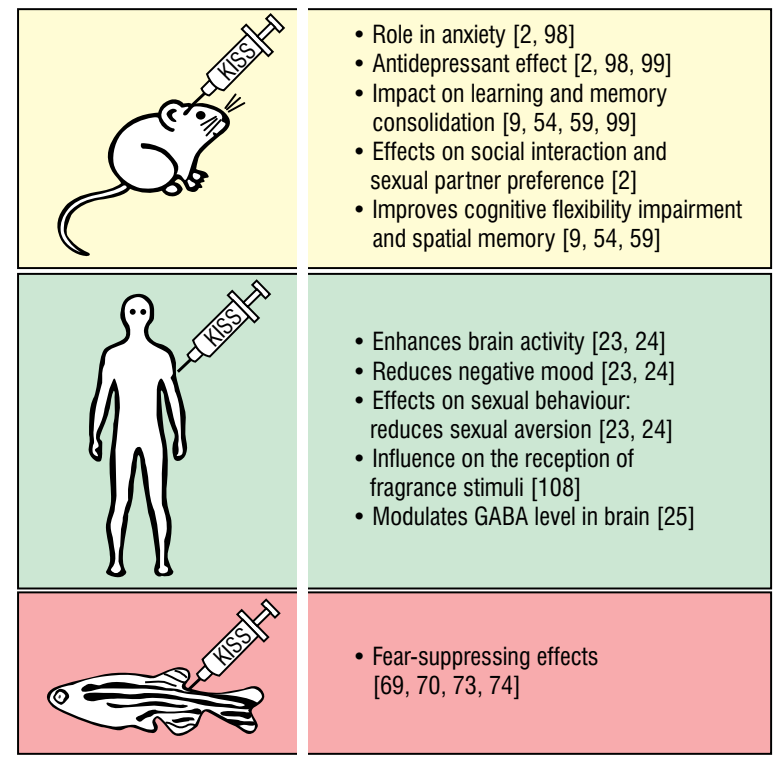

Figure 3. Summary of therapeutic roles of kisspeptin.

the coming years to investigate its role in emotion and memory function in healthy condition as well as in the diseases. The results indicating the therapeutic role of KP in neuropsychiatric and neurodegenerative diseases represent a promising path for the development of research into this problem. Future studies will, undoubtfully, investigate the influence of KP on behaviours in various species including humans and attempt to delineate the precise neuronal pathways involved. Furthermore, with a better understanding of these processes, there may emerge potential therapeutic applications to aid patients with various neurodegenerative, emotional or psychosexual diseases.

\section{Acknowledgements}

The authors thank Sylwia Scislowska, MSci for assisting in preparation of figures and Aleksandra Arceusz, MSci for English proof of the manuscript.

\section{Conflict of interest: None declared}

\section{REFERENCES}

1. Adachi S, Yamada S, Takatsu $Y$, et al. Involvement of anteroventral periventricular metastin/kisspeptin neurons in estrogen positive feedback action on luteinizing hormone release in female rats. J Reprod Dev. 2007; 53(2): 367-378, doi: 10.1262/jrd.18146, indexed in Pubmed: 17213691.

2. Adekunbi DA, Li XF, Lass G, et al. Kisspeptin neurones in the posterodorsal medial amygdala modulate sexual partner preference and anxiety in male mice. J Neuroendocrinol. 2018; 30(3): e12572, doi: 10.1111/jne.12572, indexed in Pubmed: 29356147.

3. Aggarwal S, Tang C, Sing K, et al. Medial amygdala kiss1 neurons mediate female pheromone stimulation of lute- inizing hormone in male mice. Neuroendocrinology. 2019; 108(3): 172-189, doi: 10.1159/000496106, indexed in Pubmed: 30537700.

4. Aguilar Martínez N, Aguado Carrillo G, Saucedo Alvarado PE, et al. Clinical importance of olfactory function in neurodegenerative diseases. Rev Médica del Hosp Gen México. 2018; 81(4): 268-275, doi: 10.1016/j.hgmx.2017.05.007.

5. Andreozzi F, Mannino GC, Mancuso E, et al. Plasma kisspeptin levels are associated with insulin secretion in nondiabetic individuals. PLoS One. 2017; 12(6): e0179834, doi: 10.1371/ journal.pone.0179834, indexed in Pubmed: 28636637.

6. Arai AC, Orwig N. Factors that regulate KiSS1 gene expression in the hippocampus. Brain Res. 2008; 1243: 10-18, doi: 10.1016/j.brainres.2008.09.031, indexed in Pubmed: 18834866.

7. Arai AC, Xia YF, Suzuki E, et al. Cancer metastasis-suppressing peptide metastin upregulates excitatory synaptic transmission in hippocampal dentate granule cells. J Neurophysiol. 2005; 94(5): 3648-3652, doi: 10.1152/ jn.00590.2005, indexed in Pubmed: 16222076.

8. Arai AC. The role of kisspeptin and GPR54 in the hippocampus. Peptides. 2009; 30(1): 16-25, doi: 10.1016/j. peptides.2008.07.023, indexed in Pubmed: 18765263.

9. Babaei P, Pourmir M, Babaei P, et al. Kisspeptin-13 ameliorates memory impairment induced by streptozotocin in male rats via cholinergic system. Physiology and Pharmacology. 2016; 20(1): 38-47.

10. Bhattacharya $M, B a b w a h$ AV. Kisspeptin: beyond the brain. Endocrinology. 2015; 156(4): 1218-1227, doi: 10.1210/ en.2014-1915, indexed in Pubmed: 25590245.

11. Boehm U, Zou Z, Buck LB. Feedback loops link odor and pheromone signaling with reproduction. Cell. 2005; 123(4): 683-695, doi: 10.1016/j.cell.2005.09.027, indexed in Pubmed: 16290036.

12. Brown RE, Imran SA, Ur E, et al. KiSS-1 mRNA in adipose tissue is regulated by sex hormones and food intake. Mol Cell Endocrinol. 2008; 281(1-2): 64-72, doi: 10.1016/j. mce.2007.10.011, indexed in Pubmed: 18069123.

13. Castellano JM, Bentsen AH, Mikkelsen JD, et al. Kisspeptins: bridging energy homeostasis and reproduction. Brain Res. 2010; 1364: 129-138, doi: 10.1016/j.brainres.2010.08.057, indexed in Pubmed: 20800054.

14. Cayre M, Canoll P, Goldman JE. Cell migration in the normal and pathological postnatal mammalian brain. Prog Neurobiol. 2009; 88(1): 41-63, doi: 10.1016/j.pneurobio.2009.02.001, indexed in Pubmed: 19428961.

15. Cheng G, Coolen LM, Padmanabhan V, et al. The kisspeptin/neurokinin B/dynorphin (KNDy) cell population of the arcuate nucleus: sex differences and effects of prenatal testosterone in sheep. Endocrinology. 2010; 151(1): 301-311, doi: 10.1210/en.2009-0541, indexed in Pubmed: 19880810.

16. Chilumuri A, Ashioti M, Nercessian AN, et al. Immunolocalization of kisspeptin associated with amyloid- $\beta$ deposits in the pons of an Alzheimer's disease patient. J Neurodegener Dis. 2013; 2013: 879710, doi: 10.1155/2013/879710, indexed in Pubmed: 26317001.

17. Ciaramella V, Della Corte CM, Ciardiello F, et al. Kisspeptin and cancer: molecular interaction, biological functions, and future perspectives. Front Endocrinol (Lausanne). 2018; 9: 115, doi: 10.3389/fendo.2018.00115, indexed in Pubmed: 29662466.

18. Clarke H, Dhillo WS, Jayasena CN. Comprehensive review on kisspeptin and its role in reproductive disorders. Endocrinol Metab (Seoul). 2015; 30(2): 124-141, doi: 10.3803/ EnM.2015.30.2.124, indexed in Pubmed: 26194072.

19. Clarkson J, Herbison AE. Dual phenotype kisspeptin-dopamine neurones of the rostral periventricular area of the third ventricle project to gonadotrophin-releasing 
hormone neurones. J Neuroendocrinol. 2011; 23(4): 293-301, doi: 10.1111/j.1365-2826.2011.02107.x, indexed in Pubmed: 21219482.

20. Clarkson J, Herbison AE. Postnatal development of kisspeptin neurons in mouse hypothalamus; sexual dimorphism and projections to gonadotropin-releasing hormone neurons. Endocrinology. 2006; 147(12): 5817-5825, doi: 10.1210/en.2006-0787, indexed in Pubmed: 16959837.

21. Clarkson J, d'Anglemont de Tassigny $\mathrm{X}$, Colledge $\mathrm{WH}$, et al. Distribution of kisspeptin neurones in the adult female mouse brain. J Neuroendocrinol. 2009; 21(8): 673-682, doi: 10.1111/j.1365-2826.2009.01892.x, indexed in Pubmed: 19515163.

22. Comninos AN, Anastasovska J, Sahuri-Arisoylu M, et al. Kisspeptin signaling in the amygdala modulates reproductive hormone secretion. Brain Struct Funct. 2016; 221(4): 2035-2047, doi: 10.1007/s00429-015-1024-9, indexed in Pubmed: 25758403.

23. Comninos AN, Demetriou L, Wall MB, et al. Modulations of human resting brain connectivity by kisspeptin enhance sexual and emotional functions. JCI Insight. 2018; 3(20), doi: 10.1172/jci.insight.121958, indexed in Pubmed: 30333302.

24. Comninos AN, Wall MB, Demetriou L, et al. Kisspeptin modulates sexual and emotional brain processing in humans. J Clin Invest. 2017; 127(2): 709-719, doi: 10.1172/ JCl89519, indexed in Pubmed: 28112678.

25. Comninos AN, Yang L, O'Callaghan J, et al. Kisspeptin modulates gamma-aminobutyric acid levels in the human brain. Psychoneuroendocrinology. 2021; 129: 105244, doi: 10.1016/j.psyneuen.2021.105244, indexed in Pubmed: 33975151.

26. Cravo RM, Margatho LO, Osborne-Lawrence S, et al. Characterization of Kiss1 neurons using transgenic mouse models. Neuroscience. 2011; 173: 37-56, doi: 10.1016/j.neuroscience.2010.11.022, indexed in Pubmed: 21093546

27. Csabafi K, Jászberényi M, Bagosi Z, et al. Effects of kisspeptin-13 on the hypothalamic-pituitary-adrenal axis, thermoregulation, anxiety and locomotor activity in rats. Behav Brain Res. 2013; 241: 56-61, doi: 10.1016/j. bbr.2012.11.039, indexed in Pubmed: 23219969.

28. d'Anglemont de Tassigny $X$, Fagg LA, Dixon JPC, et al. Hypogonadotropic hypogonadism in mice lacking a functional Kiss1 gene. Proc Natl Acad Sci U S A. 2007; 104(25): 10714-10719, doi: 10.1073/pnas.0704114104, indexed in Pubmed: 17563351.

29. De Bond JAP, Smith JT. Kisspeptin and energy balance in reproduction. Reproduction. 2014; 147(3): R53-R63, doi: 10.1530/REP-13-0509, indexed in Pubmed: 24327738.

30. de Roux N, Genin E, Carel JC, et al. Hypogonadotropic hypogonadism due to loss of function of the KiSS1-derived peptide receptor GPR54. Proc Natl Acad Sci U S A. 2003; 100(19): 10972-10976, doi: 10.1073/pnas.1834399100, indexed in Pubmed: 12944565.

31. Delmas S, Porteous R, Bergin DH, et al. Altered aspects of anxiety-related behavior in kisspeptin receptor-deleted male mice. Sci Rep. 2018; 8(1): 2794, doi: 10.1038/ s41598-018-21042-4, indexed in Pubmed: 29434234.

32. Desroziers E, Mikkelsen J, Simonneaux V, et al. Mapping of kisspeptin fibres in the brain of the pro-oestrous rat. J Neuroendocrinol. 2010; 22(10): 1101-1112, doi: 10.1111/j.1365-2826.2010.02053.x, indexed in Pubmed: 20673302.

33. Devere R. Smell and taste in clinical neurology: Five new things. Neurol Clin Pract. 2012; 2(3): 208-214, doi: 10.1212/CPJ.0b013e31826af199, indexed in Pubmed: 29443306.

34. Di Giorgio NP, Semaan SJ, Kim J, et al. Impaired GABAB receptor signaling dramatically up-regulates Kiss1 expression selectively in nonhypothalamic brain regions of adult but not prepubertal mice. Endocrinology. 2014; 155(3): 1033-1044, doi: 10.1210/en.2013-1573, indexed in Pubmed: 24424047.

35. Doty R. Olfactory dysfunction in Parkinson disease. Nat Rev Neurol. 2012; 8(6): 329-339, doi: 10.1038/nrneurol.2012.80.

36. Franceschini I, Lomet D, Cateau M, et al. Kisspeptin immunoreactive cells of the ovine preoptic area and arcuate nucleus co-express estrogen receptor alpha. Neurosci Lett. 2006; 401(3): 225-230, doi: 10.1016/j. neulet.2006.03.039, indexed in Pubmed: 16621281.

37. Franssen D, Tena-Sempere M. The kisspeptin receptor: A key G-protein-coupled receptor in the control of the reproductive axis. Best Pract Res Clin Endocrinol Metab. 2018; 32(2): 107-123, doi: 10.1016/j.beem.2018.01.005, indexed in Pubmed: 29678280.

38. Funes S, Hedrick JA, Vassileva G, et al. The KiSS-1 receptor GPR54 is essential for the development of the murine reproductive system. Biochem Biophys Res Commun. 2003; 312(4): 1357-1363, doi: 10.1016/j.bbrc.2003.11.066, indexed in Pubmed: 14652023.

39. Gibula-Tarlowska E, Kotlinska JH. Kissorphin improves spatial memory and cognitive flexibility impairment induced by ethanol treatment in the Barnes maze task in rats. Behav Pharmacol. 2020; 31(2\&3): 272-282, doi: 10.1097/FBP.0000000000000557, indexed in Pubmed: 32168027.

40. Goncharova ND. Stress responsiveness of the hypothalamic-pituitary-adrenal axis: age-related features of the vasopressinergic regulation. Front Endocrinol (Lausanne). 2013; 4: 26, doi: 10.3389/fendo.2013.00026, indexed in Pubmed: 23486926.

41. Goodman RL, Lehman MN, Smith JT, et al. Kisspeptin neurons in the arcuate nucleus of the ewe express both dynorphin A and neurokinin B. Endocrinology. 2007; 148(12): 5752-5760, doi: 10.1210/en.2007-0961, indexed in Pubmed: 17823266.

42. Gottsch ML, Cunningham MJ, Smith JT, et al. A role for kisspeptins in the regulation of gonadotropin secretion in the mouse. Endocrinology. 2004; 145(9): 4073-4077, doi: 10.1210/en.2004-0431, indexed in Pubmed: 15217982.

43. Han SK, Gottsch ML, Lee KJ, et al. Activation of gonadotropin-releasing hormone neurons by kisspeptin as a neuroendocrine switch for the onset of puberty. J Neurosci. 2005; 25(49): 11349-11356, doi: 10.1523/ JNEUROSCI.3328-05.2005, indexed in Pubmed: 16339030.

44. Handa RJ, Burgess LH, Kerr JE, et al. Gonadal steroid hormone receptors and sex differences in the hypothalamo-pituitary-adrenal axis. Horm Behav. 1994; 28(4): 464-476, doi: 10.1006/hbeh.1994.1044, indexed in Pubmed: 7729815.

45. Harter CJL, Kavanagh GS, Smith JT. The role of kisspeptin neurons in reproduction and metabolism. J Endocrinol. 2018; 238(3): R173-R183, doi: 10.1530/JOE-18-0108, indexed in Pubmed: 30042117.

46. Hellier V, Brock O, Candlish M, et al. Female sexual behavior in mice is controlled by kisspeptin neurons. Nat Commun. 2018; 9(1): 400, doi: 10.1038/s41467-017-02797-2, indexed in Pubmed: 29374161.

47. Herbison AE, Theodosis DT. Localization of oestrogen receptors in preoptic neurons containing neurotensin but not tyrosine hydroxylase, cholecystokinin or luteinizing hormone-releasing hormone in the male and female rat. Neuroscience. 1992; 50(2): 283-298, doi: 10.1016/03064522(92)90423-y, indexed in Pubmed: 1359459.

48. Hrabovszky $E$, Ciofi $P$, Vida $B$, et al. The kisspeptin system of the human hypothalamus: sexual dimorphism and relationship with gonadotropin-releasing hormone and neurokinin B neurons. Eur J Neurosci. 2010; 31(11): 1984-1998, doi: 10.1111/j.1460-9568.2010.07239.x, indexed in Pubmed: 20529119. 
49. Hrabovszky E, Borsay BÁ, Rácz K, et al. Substance P immunoreactivity exhibits frequent colocalization with kisspeptin and neurokinin $B$ in the human infundibular region. PLoS One. 2013; 8(8): e72369, doi: 10.1371/ journal.pone.0072369, indexed in Pubmed: 23977290.

50. Hussain MA, Song WJ, Wolfe A, et al. Glucagon regulates hepatic kisspeptin to impair insulin secretion. Cell Metab. 2014; 19(4): 667-681, doi: 10.1016/j.cmet.2014.03.005, indexed in Pubmed: 24703698.

51. Irwig MS, Fraley GS, Smith JT, et al. Kisspeptin activation of gonadotropin releasing hormone neurons and regulation of KiSS-1 mRNA in the male rat. Neuroendocrinology. 2004; 80(4): 264-272, doi: 10.1159/000083140, indexed in Pubmed: 15665556.

52. Izzi E, Comninos A, Clarke $S$, et al. Kisspeptin stimulates insulin secretion and modulates serum metabolites in humans. Endocrine Abstracts. 2018, doi: 10.1530/endoabs.59.oc3.1.

53. Izzi-Engbeaya $C$, Comninos AN, Clarke SA, et al. The effects of kisspeptin on $\beta$-cell function, serum metabolites and appetite in humans. Diabetes Obes Metab. 2018; 20(12): 2800-2810, doi: 10.1111/dom.13460, indexed in Pubmed: 29974637.

54. Jiang JH, He Z, Peng YL, et al. Kisspeptin-13 enhances memory and mitigates memory impairment induced by A 1-42 in mice novel object and object location recognition tasks. Neurobiol Learn Mem. 2015; 123: 187-195, doi: 10.1016/j.nlm.2015.05.010, indexed in Pubmed: 26103138

55. Kalló I, Mohácsik P, Vida B, et al. A novel pathway regulates thyroid hormone availability in rat and human hypothalamic neurosecretory neurons. PLoS One. 2012; 7(6): e37860, doi: 10.1371/journal.pone.0037860, indexed in Pubmed: 22719854.

56. Kauffman AS. Coming of age in the kisspeptin era: sex differences, development, and puberty. Mol Cell Endocrinol. 2010; 324(1-2): 51-63, doi: 10.1016/j.mce.2010.01.017, indexed in Pubmed: 20083160.

57. Keshavarzi S, Sullivan RKP, lanno DJ, et al. Functional properties and projections of neurons in the medial amygdala. J Neurosci. 2014; 34(26): 8699-8715, doi: 10.1523/ JNEUROSCI.1176-14.2014, indexed in Pubmed: 24966371.

58. Kevetter GA, Winans SS. Connections of the corticomedial amygdala in the golden hamster. I. Efferents of the "vomeronasal amygdala". J Comp Neurol. 1981; 197(1): 81-98, doi: 10.1002/cne.901970107, indexed in Pubmed: 6164702.

59. Khonacha SE, Janahmadi M, Motamedi F. Kisspeptin-13 Improves Spatial Memory Consolidation and Retrieval against Amyloid- $\beta$ Pathology. Iran J Pharm Res. 2019; 18(Suppl1): 169-181, doi: 10.22037/ijpr.2019.112199.13599, indexed in Pubmed: 32802097.

60. Kim J, Semaan SJ, Clifton DK, et al. Regulation of Kiss1 expression by sex steroids in the amygdala of the rat and mouse. Endocrinology. 2011; 152(5): 2020-2030, doi: 10.1210/en.2010-1498, indexed in Pubmed: 21363930.

61. Kim TH, Cho SG. Kisspeptin inhibits cancer growth and metastasis via activation of EIF2AK2. Mol Med Rep. 2017; 16(5): 7585-7590, doi: 10.3892/mmr.2017.7578, indexed in Pubmed: 28944853.

62. Lee DK, Nguyen T, O'Neill GP, et al. Discovery of a receptor related to the galanin receptors. FEBS Lett. 1999; 446(1): 103-107, doi: 10.1016/s0014-5793(99)00009-5, indexed in Pubmed: 10100623.

63. Lee JH, Miele ME, Hicks DJ, et al. KiSS-1, a novel human malignant melanoma metastasis-suppressor gene. J Natl Cancer Inst. 1996; 88(23): 1731-1737, doi: 10.1093/ jnci/88.23.1731, indexed in Pubmed: 8944003.

64. Lee JH, Welch DR. Identification of highly expressed genes in metastasis-suppressed chromosome 6/human malignant melanoma hybrid cells using subtractive hybridization and differential display. Int J Cancer. 1997; 71(6): 1035-1044, doi: 10.1002/(sici)1097-0215(19970611)71:6<1035::aidijc20>3.0.co;2-b, indexed in Pubmed: 9185708.

65. Lehman MN, Hileman SM, Goodman RL. Neuroanatomy of the kisspeptin signaling system in mammals: comparative and developmental aspects. Adv Exp Med Biol. 2013; 784: 27-62, doi: 10.1007/978-1-4614-6199-9_3, indexed in Pubmed: 23550001.

66. Lehman MN, Merkley CM, Coolen LM, et al. Anatomy of the kisspeptin neural network in mammals. Brain Res. 2010; 1364: 90-102, doi: 10.1016/j.brainres.2010.09.020, indexed in Pubmed: 20858464.

67. Martínez-Fuentes AJ, Molina M, Vázquez-Martínez R, et al. Expression of functional KISS1 and KISS1R system is altered in human pituitary adenomas: evidence for apoptotic action of kisspeptin-10. Eur J Endocrinol. 2011; 164(3): 355-362, doi: 10.1530/EJE-10-0905, indexed in Pubmed: 21169415.

68. Milton NGN, Chilumuri A, Rocha-Ferreira E, et al. Kisspeptin prevention of amyloid- peptide neurotoxicity in vitro. ACS Chem Neurosci. 2012; 3(9): 706-719, doi: 10.1021/ cn300045d, indexed in Pubmed: 23019497.

69. Nathan FM, Ogawa S, Parhar IS. Kisspeptin1 modulates odorant-evoked fear response via two serotonin receptor subtypes (5-HT1 A and 5-HT2) in zebrafish. J Neurochem. 2015; 133(6): 870-878, doi: 10.1111/jnc.13105, indexed in Pubmed: 25818845.

70. Nathan FM, Ogawa S, Parhar IS. Neuronal connectivity between habenular glutamate-kisspeptin 1 co-expressing neurons and the raphe 5-HT system. J Neurochem. 2015; 135(4): 814-829, doi: 10.1111/jnc.13273, indexed in Pubmed: 26250886.

71. Navarro VM. Metabolic regulation of kisspeptin: the link between energy balance and reproduction. Nat Rev Endocrinol. 2020; 16(8): 407-420, doi: 10.1038/s41574020-0363-7, indexed in Pubmed: 32427949.

72. Neuman-Lee L, Greives T, Hopkins GR, et al. The role of the kisspeptin system in regulation of the reproductive endocrine axis and territorial behavior in male sideblotched lizards (Uta stansburiana). Horm Behav. 2017; 89: 48-54, doi: 10.1016/j.yhbeh.2016.12.006, indexed in Pubmed: 28017596.

73. Ogawa S, Nathan FM, Parhar IS. Habenular kisspeptin modulates fear in the zebrafish. Proc Natl Acad Sci U S A. 2014; 111(10): 3841-3846, doi: 10.1073/ pnas.1314184111, indexed in Pubmed: 24567386.

74. Ogawa S, Parhar IS. Biological significance of kisspeptin-Kiss 1 receptor signaling in the habenula of teleost species. Front Endocrinol (Lausanne). 2018; 9: 222, doi: 10.3389/fendo.2018.00222, indexed in Pubmed: 29867758.

75. Pandya M, Altinay M, Malone DA, et al. Where in the brain is depression? Curr Psychiatry Rep. 2012; 14(6): 634-642, doi: 10.1007/s11920-012-0322-7, indexed in Pubmed: 23055003.

76. Petit-Demouliere B, Chenu F, Bourin M. Forced swimming test in mice: a review of antidepressant activity. Psychopharmacology (Berl). 2005; 177(3): 245-255, doi: 10.1007/ s00213-004-2048-7, indexed in Pubmed: 15609067.

77. Pineda R, Aguilar E, Pinilla L, et al. Physiological roles of the kisspeptin/GPR54 system in the neuroendocrine control of reproduction. Prog Brain Res. 2010; 181: 55-77, doi: 10.1016/S0079-6123(08)81005-9, indexed in Pubmed: 20478433.

78. Pineda R, Plaisier F, Millar RP, et al. Amygdala kisspeptin neurons: putative mediators of olfactory control of the gonadotropic axis. Neuroendocrinology. 2017; 104(3): 223-238, doi: 10.1159/000445895, indexed in Pubmed: 27054958.

79. Porteous R, Petersen SL, Yeo SH, et al. Kisspeptin neurons co-express met-enkephalin and galanin in the rostral pe- 
riventricular region of the female mouse hypothalamus. J Comp Neurol. 2011; 519(17): 3456-3469, doi: 10.1002/ cne.22716, indexed in Pubmed: 21800299.

80. Preston $A R$, Eichenbaum $H$. Interplay of hippocampus and prefrontal cortex in memory. Curr Biol. 2013; 23(17): R764-R773, doi: 10.1016/j.cub.2013.05.041, indexed in Pubmed: 24028960.

81. Rajmohan V, Mohandas E. The limbic system. Indian J Psychiatry. 2007; 49(2): 132-139, doi: 10.4103/00195545.33264, indexed in Pubmed: 20711399.

82. Roa J, Tena-Sempere M. Connecting metabolism and reproduction: roles of central energy sensors and key molecular mediators. Mol Cell Endocrinol. 2014; 397(1-2): 4-14, doi: 10.1016/j.mce.2014.09.027, indexed in Pubmed: 25289807.

83. Roseweir AK, Kauffman AS, Smith JT, et al. Discovery of potent kisspeptin antagonists delineate physiological mechanisms of gonadotropin regulation. J Neurosci. 2009; 29(12): 3920-3929, doi: 10.1523/JNEUROSCl.5740-08.2009, indexed in Pubmed: 19321788.

84. Rumpler É. Identification of species-specific and general features in the anatomy of the kisspeptin neuron system. PhD Thesis Semmelweis University, Budapest 2021.

85. Saedi S, Khoradmehr A, Mohammad Reza JS, et al. The role of neuropeptides and neurotransmitters on kisspeptin/kiss1r-signaling in female reproduction. J Chem Neuroanat. 2018; 92: 71-82, doi: 10.1016/j. jchemneu.2018.07.001, indexed in Pubmed: 30008384.

86. Sanchez-Garrido MA, Tena-Sempere M. Metabolic control of puberty: roles of leptin and kisspeptins. Horm Behav. 2013; 64(2): 187-194, doi: 10.1016/j.yhbeh.2013.01.014, indexed in Pubmed: 23998663.

87. Sarkar S, Raymick J, Imam S. Neuroprotective and therapeutic strategies against parkinson's disease: recent perspectives. Int J Mol Sci. 2016; 17(6), doi: 10.3390/ ijms17060904, indexed in Pubmed: 27338353.

88. Scott CJ, Rose JL, Gunn AJ, et al. Kisspeptin and the regulation of the reproductive axis in domestic animals. J Endocrinol. 2018 [Epub ahead of print], doi: 10.1530/ JOE-18-0485, indexed in Pubmed: 30400056.

89. Seminara SB, Messager S, Chatzidaki EE, et al. The GPR54 gene as a regulator of puberty. N Engl J Med. 2003; 349(17): 1614-1627, doi: 10.1056/NEJMoa035322, indexed in Pubmed: 14573733.

90. Skorupskaite K, George JT, Anderson RA. The kisspeptin-GnRH pathway in human reproductive health and disease. Hum Reprod Update. 2014; 20(4): 485-500, doi: 10.1093/humupd/dmu009, indexed in Pubmed: 24615662

91. Smith JT, Shahab M, Pereira A, et al. Hypothalamic expression of KISS1 and gonadotropin inhibitory hormone genes during the menstrual cycle of a non-human primate. Biol Reprod. 2010; 83(4): 568-577, doi: 10.1095/ biolreprod.110.085407, indexed in Pubmed: 20574054.

92. Smith JT, Cunningham MJ, Rissman EF, et al. Regulation of Kiss1 gene expression in the brain of the female mouse. Endocrinology. 2005; 146(9): 3686-3692, doi: 10.1210/ en.2005-0488, indexed in Pubmed: 15919741.

93. Smith JT, Dungan HM, Stoll EA, et al. Differential regulation of KiSS-1 mRNA expression by sex steroids in the brain of the male mouse. Endocrinology. 2005; 146(7): 2976-2984, doi: 10.1210/en.2005-0323, indexed in Pubmed: 15831567.

94. Stengel A, Wang L, Goebel-Stengel M, et al. Centrally injected kisspeptin reduces food intake by increasing meal intervals in mice. Neuroreport. 2011; 22(5): 253-257, doi: 10.1097/ WNR.0b013e32834558df, indexed in Pubmed: 21386700.

95. Stephens SBZ, Chahal N, Munaganuru N, et al. Estrogen stimulation of Kiss1 expression in the medial amygdala involves estrogen receptor- $\alpha$ but not estrogen receptor- $\beta$. Endocrinology. 2016; 157(10): 4021-4031, doi: 10.1210/ en.2016-1431, indexed in Pubmed: 27564649.

96. Stephens S, Kauffman A. Regulation and possible functions of kisspeptin in the medial amygdala. Front Endocrinol. 2017; 8, doi: 10.3389/fendo.2017.00191.

97. Takamura R, Mizuta K, Sekine Y, et al. Modality-Specific impairment of hippocampal CA1 neurons of alzheimer's disease model mice. J Neurosci. 2021; 41(24): 5315-5329, doi: 10.1523/JNEUROSCI.0208-21.2021, indexed in Pubmed: 33980545.

98. Tanaka M, Csabafi K, Telegdy G. Neurotransmissions of antidepressant-like effects of kisspeptin-13. Regul Pept. 2013; 180: 1-4, doi: 10.1016/j.regpep.2012.08.017, indexed in Pubmed: 22999921.

99. Telegdy G, Adamik Á. The action of kisspeptin-13 on passive avoidance learning in mice. Involvement of transmitters. Behav Brain Res. 2013; 243: 300-305, doi: 10.1016/j. bbr.2013.01.016, indexed in Pubmed: 23348107.

100. Teles MG, Bianco SDC, Brito VN, et al. A GPR54-activating mutation in a patient with central precocious puberty. N Engl J Med. 2008; 358(7): 709-715, doi: 10.1056/NEJMoa073443, indexed in Pubmed: 18272894.

101. Tomikawa J, Homma T, Tajima S, et al. Molecular characterization and estrogen regulation of hypothalamic KISS1 gene in the pig. Biol Reprod. 2010; 82(2): 313-319, doi: 10.1095/biolreprod.109.079863, indexed in Pubmed: 19828777.

102. Trujillo MV, Kalil B, Ramaswamy S, et al. Estradiol upregulates kisspeptin expression in the preoptic area of both the male and female rhesus monkey (Macaca mulatta): implications for the hypothalamic control of ovulation in highly evolved primates. Neuroendocrinology. 2016; 105(1): 77-89, doi: 10.1159/000448520.

103. Tsatsanis C, Dermitzaki E, Avgoustinaki P, et al. The impact of adipose tissue-derived factors on the hypothalamic-pituitary-gonadal (HPG) axis. Hormones (Athens). 2015; 14(4): 549-562, doi: 10.14310/horm.2002.1649, indexed in Pubmed: 26859602.

104. Tsigos C, Chrousos GP. Hypothalamic-pituitary-adrenal axis, neuroendocrine factors and stress. J Psychosom Res. 2002; 53(4): 865-871, doi: 10.1016/s0022-3999(02)00429-4, indexed in Pubmed: 12377295.

105. Wahab F, Atika B, Shahab M, et al. Kisspeptin signalling in the physiology and pathophysiology of the urogenital system. Nat Rev Urol. 2016; 13(1): 21-32, doi: 10.1038/ nrurol.2015.277, indexed in Pubmed: 26620614.

106. Watanabe $Y$, Uenoyama $Y$, Suzuki J, et al. Oestrogen-induced activation of preoptic kisspeptin neurones may be involved in the luteinising hormone surge in male and female Japanese monkeys. J Neuroendocrinol. 2014; 26(12): 909-917, doi: 10.1111/jne.12227, indexed in Pubmed: 25283748.

107. Yan HC, Cao X, Das M, et al. Behavioral animal models of depression. Neurosci Bull. 2010; 26(4): 327-337, doi: 10.1007/s12264-010-0323-7, indexed in Pubmed: 20651815.

108. Yang L, Demetriou L, Wall M, et al. OR06-2 kisspeptin enhances brain processing of olfactory and visual cues of attraction in men. J Endocr Soc. 2019; 3(Suppl_1), doi: 10.1210/js.2019-or06-2.

109. Yeo SH, Kyle V, Morris PG, et al. Visualisation of Kiss1 Neurone Distribution Using a Kiss1-CRE Transgenic Mouse. J Neuroendocrinol. 2016; 28(11), doi: 10.1111/jne.12435, indexed in Pubmed: 27663274.

110. Zhang Y, Proenca R, Maffei M, et al. Positional cloning of the mouse obese gene and its human homologue. Nature. 1994; 372(6505): 425-432, doi: 10.1038/372425a0, indexed in Pubmed: 7984236. 